\title{
Effective Positioning of Shear Wall in G+5 Storey Building on Sloping Ground
}

\author{
Ankit Dane, Umesh Pendharkar
}

\begin{abstract}
Earthquake is a natural calamity. It has been observed that the earthquake has proved to be more fatal in today's time. The prime reason for this catastrophe is the extermination of the man-made structures during the earthquake, Lack of lateral strength and stability in the manmade structure is the prime reason for their demolition during the earthquake. Mostly man-made structure is multistory buildings for this reason that is necessary for the multistory building to withstand against seismic activities. For the past few decades, some new methods have been adopted to make multistory building laterally strong and stable, a shear wall is one of them which are a structural member which provides lateral stiffness and strength to the structure. The earthquake can be even more lethal on sloping land. This paper studies the influence of shear wall in the multistory building built on sloping ground. For this purpose, four different models have been taken. Modal one is the conventional rigid frame building and the remaining three models are kept with the shear wall. All conditions (ground slope, material, seismic zone, soil condition, etc.) Except for the size of the shear wall are identical. The linear static analysis has been carried out to evaluate the story shear and its reduction as a result in all three cases. The entire analysis is done on software called sap: 2000.

Keywords: seismic load, shear wall, sloppy ground, rigid frame structure, and sap: 2000.
\end{abstract}

\section{INTRODUCTION}

It is usually saying that it's not the earthquake which kills people but it's the bad engineering which kills people. This proverb is not spoken in old times. Because there was no large man-made creation in those times only natural made things were. As time went on, the effect of the earthquake began to increase due to the destruction of man-made creations. And among them, the multistory building is a huge man-made creation. As multistory building started to collapse everywhere due to the earthquake, the loss of public and goods started as well then a new term came into existence to reduce the effect of this catastrophe called seismology. Seismology is the study of vibration of the earth mainly by earthquakes. The study of this vibration by various techniques understanding the nature and various physical processes that generate from the major part. Elastic rebound theory is one such theory, which was able to describe the phenomenon of an earthquake occurring along the fault line. Seismology as such is still a much unknown field of study where a lot of things are yet to be discovered.

Revised Manuscript Received on December 30, 2019

* Correspondence Author

Ankit Dane*, Pursuing Masters, Specialization of Computer Aided Structural Design and Drafting Branch, Ujjain Engineering, College, Ujjain, M.P., India.

Umesh Pendharkar*, Professor, Department of civil Engineering, Ujjain Engineering College, Ujjain (M.P.), India

(c) The Authors. Published by Blue Eyes Intelligence Engineering and Sciences Publication (BEIESP). This is an open access article under the CC BY-NC-ND license (http://creativecommons.org/licenses/by-nc-nd/4.0/)
According to the rebound theory, the probability of occurrence of the earthquake on any place depends on its geographical and geological conditions too.

Geological features have spatial importance in a certain area. Construction is taking place even in difficult circumstances given the need for space in today`s times. The situation for constructing a multistory building on the sloping ground remains in India too. In the hilly region traditional material like the adobe brunt brick stone masonry, timber reinforced concrete, bamboo, etc. Which are locally available, is used for the construction of the houses.Economic growth and rapid urbanization in the hilly region have accelerated the real estate development due to this population density in the hilly region that increased enormously. Therefore there is popular and pressing demand for construction of the multistory building on a hill slope in and around the cities. A scarcity of plain ground in hilly area compels the construction activity on slopping ground. Hill building constructed in masonry with mud mortar/cement mortar without confirming to code provision have proved unsafe and, resulting in the loss of life and properties when subjected to earthquake ground motion. Therefore it is mandatory to apply a system to resisting earthquake. Now a day's many structural forms are used to resist earthquake in multistory buildings which are given below.

1. Rigid frame structure (most commonly used).

2. Shear wall-frame structure.

3. Braced frame structure.

4. Arches and cable structure.

5. Core structure.

6. Outrigger structure

7. In-filled wall-frame structure etc.

Appropriate structural forms are used as requirements. The shear wall-frame structure has been taken in interest in the presented paper. The term shear wall refers to a wall that opposes lateral wind or earthquake loads acting parallel to the plane of the wall in addition to gravity loads from the floor and roof adjacent to the wall. Since plastic hinges are made in beams and columns, not in shear walls therefor shear wall system is more reliable. A great advantage of the shear wall is that it reduces the lateral sway of the building.

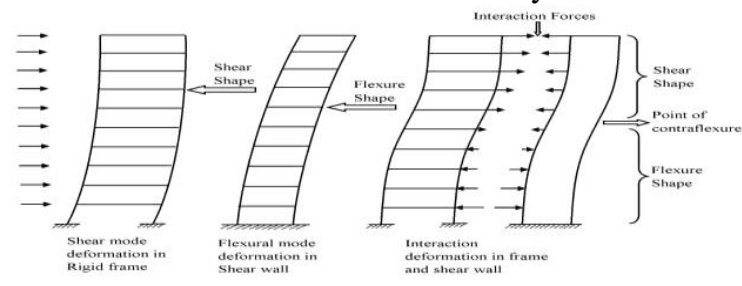

Figure 1: the action of shear wall-frame structure

Published By: 
The shear mode deformation in a rigid frame, flexural mode deformation in the shear wall and interaction deformation in frame and shear wall have given in the fig (1). It shows that how both of them compensate deformation of each other and reduce the overall deflection of the building by reversal action of deformation.

\section{GEOMETRY AND DETAILING OF SHEAR WALL}

Shear walls are oblong in cross-section i.e. the one dimension of the section is much longer than the other one. Here this paper using three different sizes as $0.25 \mathrm{~m}^{*} 0.5 \mathrm{~m}$, $.0 .25 \mathrm{~m} * 1 \mathrm{~m}$ and $0.25 \mathrm{~m} * 1.5 \mathrm{~m}$ shear walls having longer dimension is along the $\mathrm{X}$ direction as shown below in fig(2).

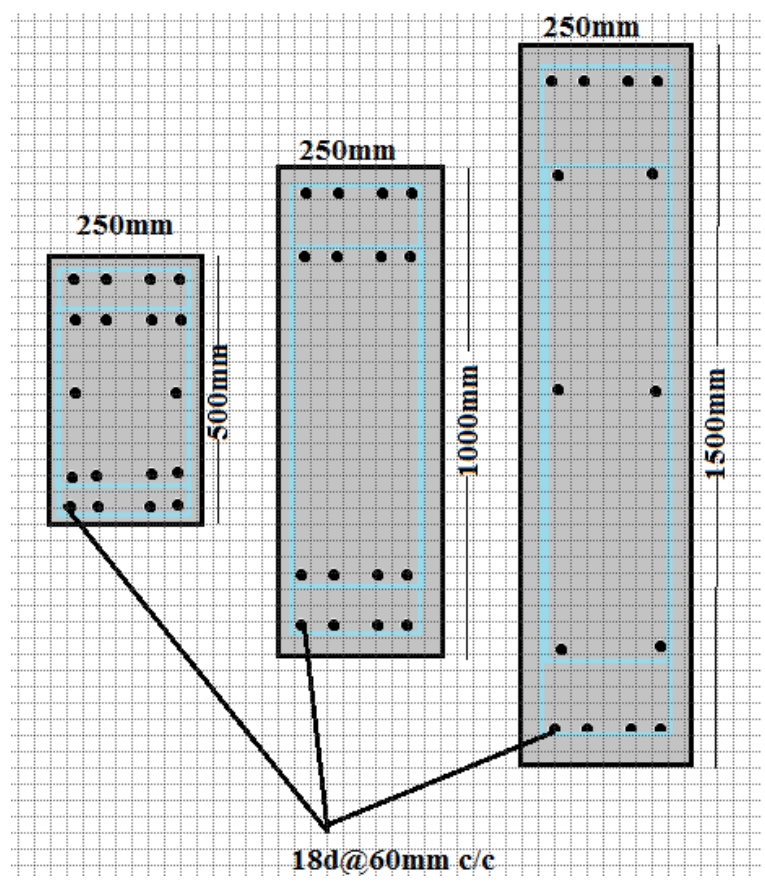

Figure 2: Cross-sectional details of all three shear walls

They are designed as per procedure is given in code IS456: 2000. According to is-13920:1993, clause 9.1.2, the minimum thickness of the shear wall should be $150 \mathrm{~mm}$. This paper takes $250 \mathrm{~mm}$ thick wall. The shear wall starts from the foundation and continues throughout the height of the building. $\mathrm{M}_{20}$ grade of concrete and $\mathrm{Fe}_{500}$ grade of steel has been used. The steel rebar is provided in the shear wall with $60 \mathrm{~mm}$ spacing in longitudinal, the minimum area of reinforcement to be provided should be 0.0025 times of the cross-section for the shear walls. Across the wall crosssections, the vertical reinforcement should be distributed uniformly.The required area of reinforcement provided automatically by software and diameter of rebar taken manually as $18 \mathrm{~mm}$.

\section{MODELING AND ANALYSIS}

This works deals with the study of a $\mathrm{G}+5$ story rigid framed concrete structure that rests on an 18.5-degree slope. The major task is to find out the optimum location of the shear walls in the frames. The present frame is subjected to the gravity and seismic loads of combination accordance to IS4562000 .
The following steps are involving in the full analysis given below.

Step 1- The selection of building geometry and seismic zone: The behavior of the models with different location of shear wall is studied for seismic zone $\mathrm{V}$ of India as per IS code $-1893: 2002$, for which zone factor $(Z)$ is 0.36 .

Step 2- The type of primary load and load combinations: The structural system are subjected to primary load cases as per IS: 4562000 and IS: 1893 2002, seven primary loads and fourteen load combination used for analysis.

Step 3- modeling of building a frame using sap: 2000 software.

Step 4- analysis of the building frames are done under seismic zone $\mathrm{V}$ for each load combination.

Step 5- a comparative study of results in term of story shear of all Models.

The following assumptions have been taken before the start of the modeling procedure for maintaining the same conditions for all three models.

1. Only man block of the building is considered, the staircases are not considered in the design procedure.

2. The building has been designed according to a residential building.

3. The slab is also provided on the ground floor.

4. For all structural elements, $\mathbf{M}_{20}$ and $\mathrm{Fe}_{500}$ grades are adopted.

5. The footings are not designed; supports are assigning as fixed support.

The specification of all members and the magnitude of dead, live and seismic loads are shown in table (1) and table (2) respectively given.

Table: 1

\begin{tabular}{|r|l|l|}
\hline SN & LOAD APPLIED & magnitude \\
\hline 1 & Self-weight of beam & $3.75 \mathrm{KN} / \mathrm{m}$ \\
\hline 2 & $\begin{array}{l}\text { Self -weight of partition } \\
\text { wall }\end{array}$ & $12.5 \mathrm{KN} / \mathrm{m}$ \\
\hline 3 & Self- weight of the slab & $3.125 \mathrm{KN} / \mathrm{m}^{2}$ \\
\hline 4 & $\begin{array}{l}\text { Self - weight of parapet } \\
\text { wall }\end{array}$ & $5.52 \mathrm{KN} / \mathrm{m}$ \\
\hline 5 & Live load & $2.5 \mathrm{KN} / \mathrm{m}^{2}$ \\
\hline 6 & $\begin{array}{l}\text { Earthquake load in X- } \\
\text { direction }\end{array}$ & $\begin{array}{l}\text { As per IS: } 1893- \\
2002\end{array}$ \\
\hline 7 & $\begin{array}{l}\text { Earthquake load in Y- } \\
\text { direction }\end{array}$ & $\begin{array}{l}\text { As per IS: } 1893- \\
2002\end{array}$ \\
\hline
\end{tabular}

Table: 2

\begin{tabular}{|r|l|l|}
\hline SN & SPECIFICATIONS & SIZE \\
\hline 1 & Plan dimension & $20 \mathrm{~m}^{*} 12 \mathrm{~m}$ \\
\hline 2 & $\begin{array}{l}\text { Length in X- } \\
\text { direction }\end{array}$ & $20 \mathrm{~m}$ (4 bays) \\
\hline
\end{tabular}




\begin{tabular}{|r|l|l|}
\hline 3 & $\begin{array}{l}\text { Length in Y- } \\
\text { direction }\end{array}$ & $12 \mathrm{~m}$ (2 bays) \\
\hline 4 & $\begin{array}{l}\text { Height in Z- } \\
\text { direction }\end{array}$ & $18 \mathrm{~m}$ \\
\hline 5 & Floor to floor height & $3 \mathrm{~m}$ \\
\hline 6 & $\begin{array}{l}\text { The total height of } \\
\text { the building (G+5) }\end{array}$ & $18 \mathrm{~m}$ \\
\hline 7 & Slab thickness & $125 \mathrm{~mm}$ \\
\hline 8 & $\begin{array}{l}\text { Soil type (as per IS: } \\
1893-2000)\end{array}$ & II \\
\hline 9 & Importance factor & 1 \\
\hline 10 & Seismic zone factor & 0.36 \\
\hline 11 & Grade of concrete & M20 \\
\hline 12 & Grade of steel & Fe500 \\
\hline 13 & Floor beam size & $0.3 \mathrm{~m} * 0.5 \mathrm{~m}$ \\
\hline 14 & Column size & $0.35 \mathrm{~m} * 0.35 \mathrm{~m}$ \\
\hline 15 & Load combination & $1.5 \mathrm{DL}+1.5 \mathrm{EQX}$ \\
\hline & \multicolumn{2}{|l}{} \\
\hline
\end{tabular}

This Modal is analyzing for an identical loading case which is an earthquake force applying towards the direction of the downward slope side, fig (3) shows that.

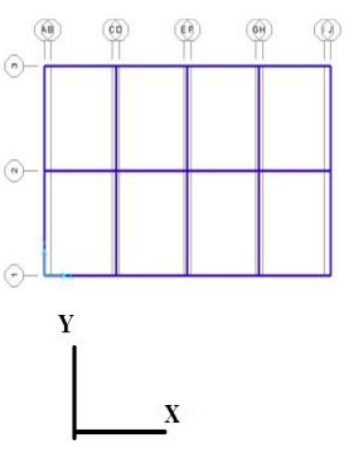

PLAN

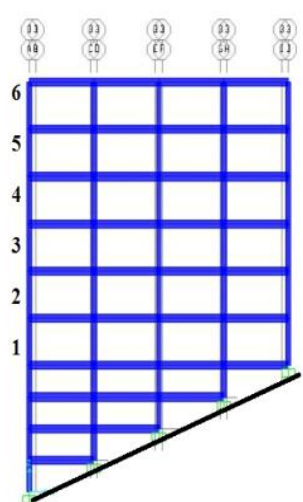

SIDE VIEW

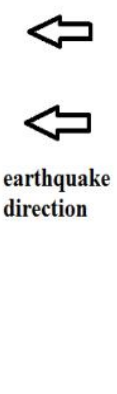

Figure: 3 Plan and side view of conventional modal.

The building is modeled using FEM based software SAP 2000. Beams and columns are modeled as double nodded beam element with 6 degrees of freedom at each node. Shear element with the third orthogonal dimension is very smaller than the other two orthogonal dimensionsA conventional building frame has been given in fig (3) in which no shear wall has been applied. Besides that three different models are taken in which the size of the shear wall is different too. Description of all three modal is given below.

MODAL (1) - $\quad 0.25 \mathrm{~m}$ thick and $0.5 \mathrm{~m}$ wide shear $\quad$ wall is injected at 5 different locations

MODAL (2) - $\quad 0.25 \mathrm{~m}$ thick and $1.0 \mathrm{~m}$ wide shear wall is injected at 5 different locations

MODAL (3) - $\quad 0.25 \mathrm{~m}$ thick and $1.5 \mathrm{~m}$ wide shear wall is injected at 5 different locations

This is considered for all three models have a rigid connection between the shear wall and building frame. Three cases are given in fig (3), fig (4) and fig (5). The subfigures (a), (b), (c), (d), and (e) located in three figures wall and slab members are modeled by using thin shell
(3), (4) and (5) shows those five locations of shear walls at $\mathrm{AA}^{*}, \mathrm{BB}^{*}, \mathrm{CC}^{*}, \mathrm{DD}^{*}$ and $\mathrm{EE}^{*}$ respectively.

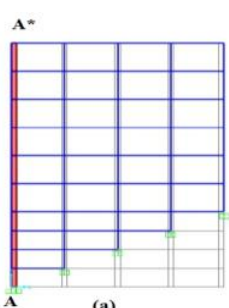

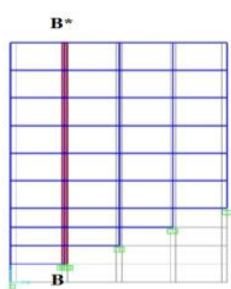

(b)

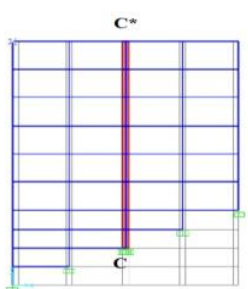

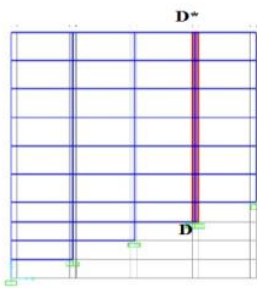

(d)

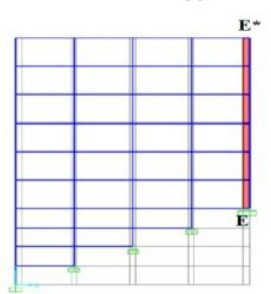

(e)
Figure 4: modal (1)
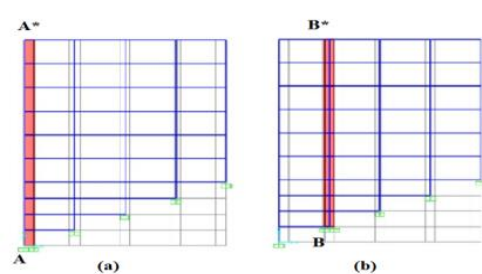

(b)

$\mathbf{D}^{*}$

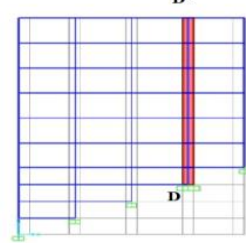

(d)

Figure 5: modal (2)

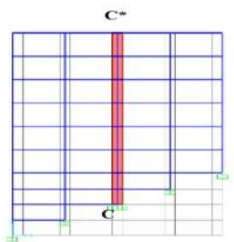

(c)

E*

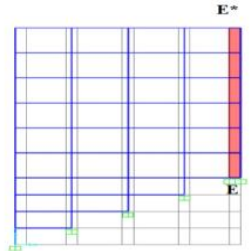

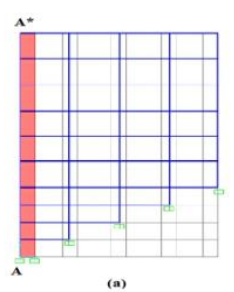

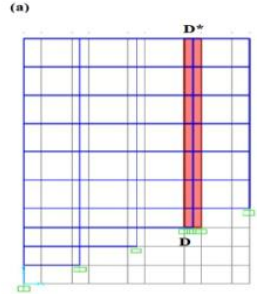

(a)

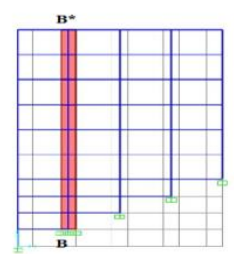

(b)

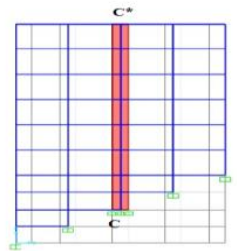

(c)

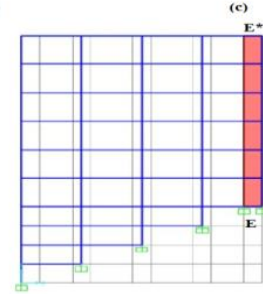

(e)
Figure 6: modal (3)

\section{RESULTS AND DISCUSSION}

Result of linear static analysis as per IS 1893:2002 (part 1) on the above three models with respect to story shear $(\mathrm{KN})$ are shown in the next figures. 
Percentage reduction in story shear as compared with conventional (frame type) structural system is also

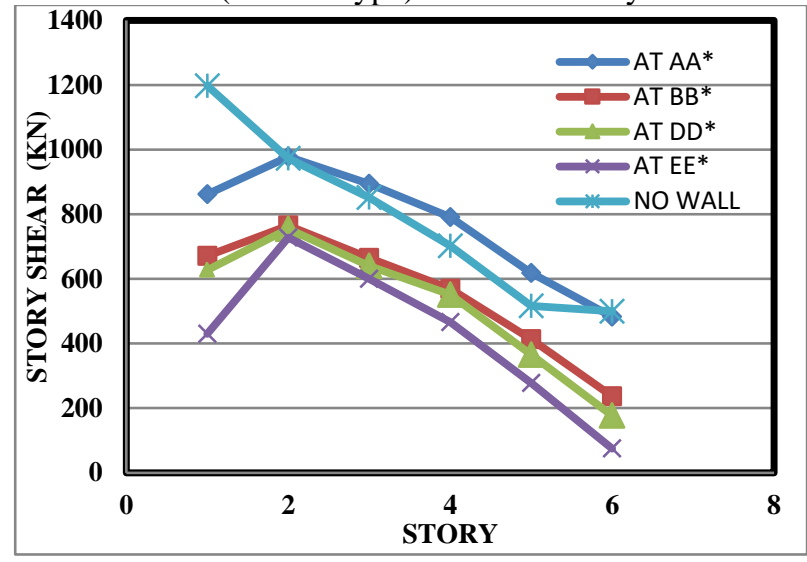

Figure 7: modal (1)

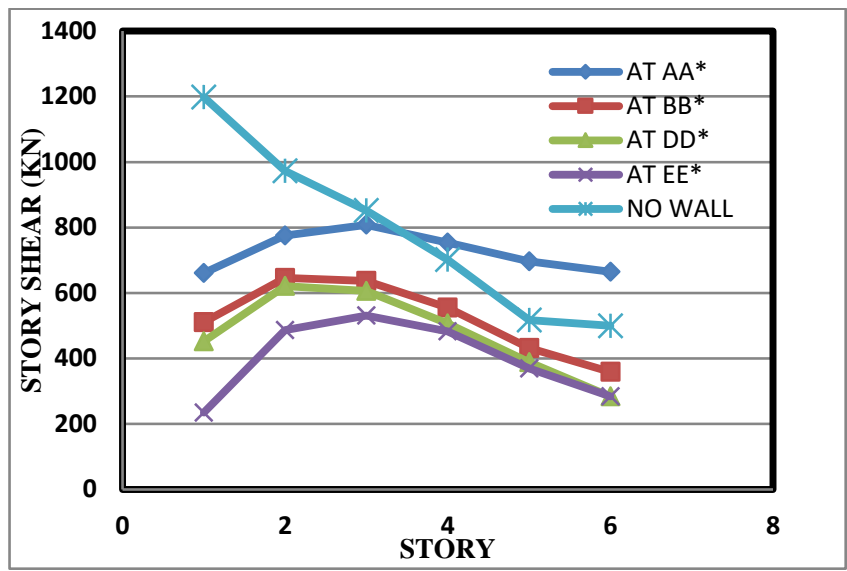

Figure 9: modal (3)

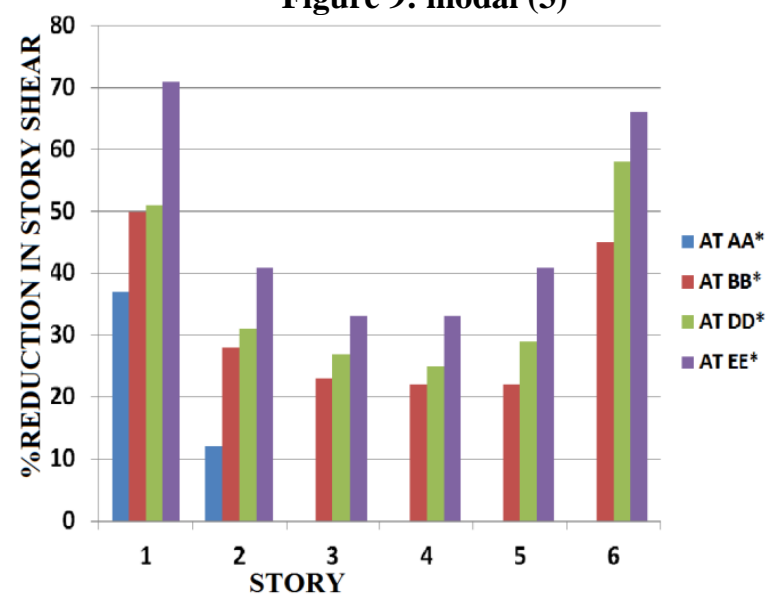

Figure 11: modal (2)

With the Discussion of the appropriate results, It is clear from the figure (7), (8) and (9) shown above, Shear wall provided towards upward slope-side gives minimum story shear force on each story which is EE* location. But when shear walls were placed on EE* location, then a huge difference was seen between the story shear [see figure (7), (8), (9)] of the first and second story which can induce the diagonal shear failure on the short-column side. That's why the second nearest location to upward slope-side will be considered as the optimum location of the shear wall which is DD* location. Percentage reduction in story shear represented.

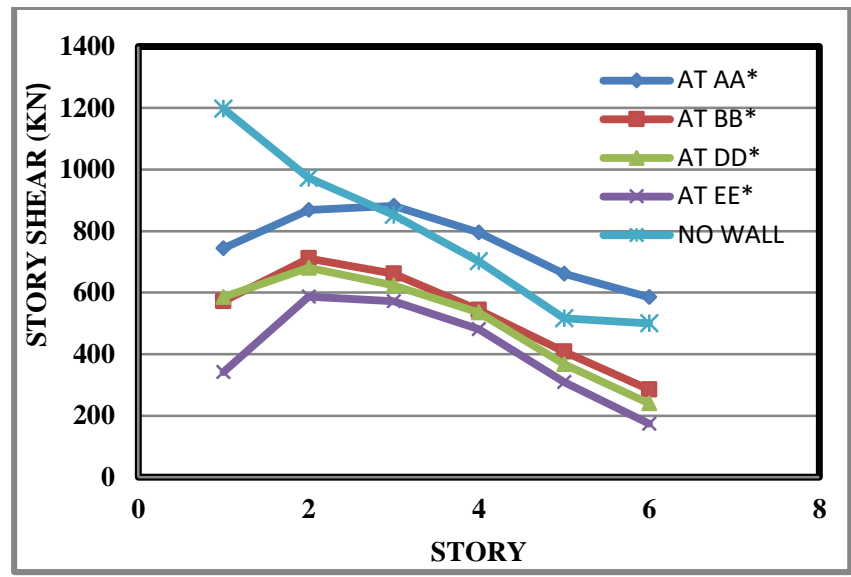

Figure 8: modal (2)

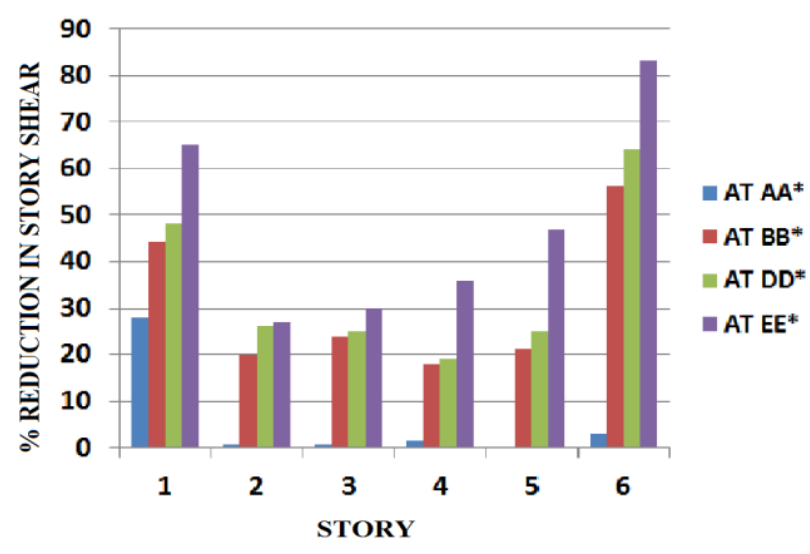

Figure 10: modal (1)

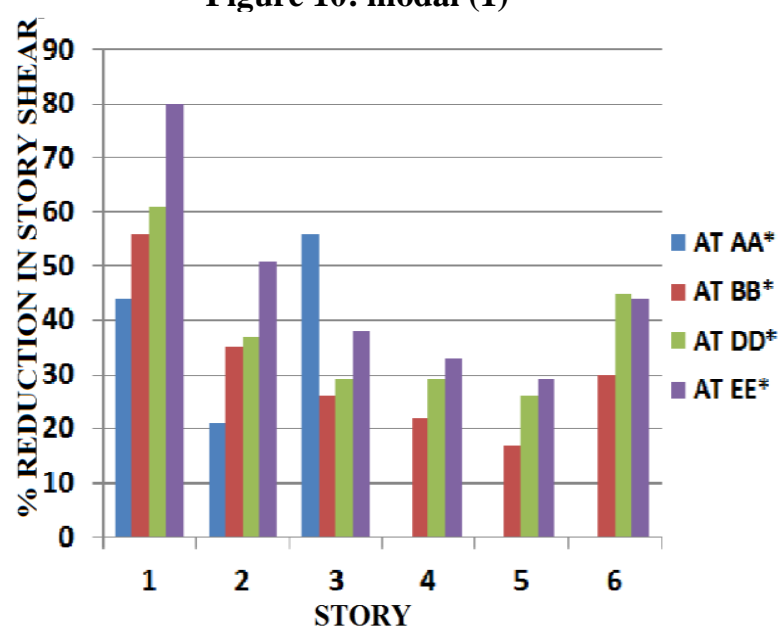

Figure 12: modal (3)

compare with conventional frame building is given for all three cases in figure (10), (11) and (12). It has been found from this result as an increase in the size of shear walls; story shear reduces at lower floors and increases at upper floors. In this paper, model (1) gives economical results in terms of cost and strength (story shear) therefor figures 4 . (d) [i.e. modal (1) with shear wall at $\mathrm{DD}^{*}$ location] will be the best configuration.

Published By: 


\section{CONCLUSION}

1. The study concludes that when the shear walls are applied toward the upward slope side, it works effectively.

2. When shear walls were placed on EE* location a huge difference has been seen between the story shear [see figure (7), (8), (9)] of the first and second story which can induce the diagonal shear failure on the shortcolumn side. That's why the second nearest location to upward side will be considered as the optimum location of the shear wall which is DD* location. Therefore the second near location to the upward slope (DD*) is most effective in resisting story shear.

3. There is an average of $34.5 \%, 36.8 \%$ and $37.8 \%$ reduction in story shear has been observed for modal (1), modal (2) and modal (3) respectively with wall at DD* location.

4. There is a maximum of $64 \%, 58 \%$ and $64 \%$ reduction in story shear has been observed for modal (1), modal (2) and modal (3) respectively with wall at $\mathrm{DD}^{*}$ location

5. Model (1) is found more economical and effective than the other two models which are shown in the fig (5), (6), and (7).

6. Maximum reduction in story shear is found $64 \%$ in a modal (3) which is shown in the figure: 6 .

7. $65 \%, 71 \%$ and $80 \%$ of reduction in base shear are observed in a modal (1), modal (2) and modal (3) respectively, which indicates the model (3) shows more susceptibility in term of base shear only.

\section{REFERENCES}

1. Yu Zhang, Caitlin Mueller (2017), shear wall layout optimization for conceptual design of the tall building, American society of engineering structures, volume 140, page 225-240.

2. S. Kumar, V. Garg, A. Sharma (2014) effect of the sloping ground structural performance of RCC building under seismic load, International journal of scientific \& engineering research, volume 2, issue 6, page 1310-1321.

3. A.Joshua Denial, S Sivakamasundari (2016), seismic vulnerability of building on the hill slope, international general of earth science and engineering volume 9, no.5, page 1892-199.

4. R.P. Vaidya, (2011) seismic analysis of building with the shear wall on sloppy ground, International Journal of Civil and Structural Engineering research volume 2, page 53-60.

5. T. Magendra., A. Ttiksh, A.A. Qureshi (2016), Optimum positioning of shear wall in a multistory building, international journal of research and development volume 3 no. 3 page 666-671

6. Mr.Madhu, Sudhan, Rao.Rondapalli International journal of scientific \& engineering research, volume 9, issue 7, July-2018 page 22295518.

7. Md. Rokanuzzaman, Farjana Khanam, Anik das, S. Reza Chowdhury International Journal of Advances in Mechanical and Civil Engineering, ISSN: 2394-2827 Volume-4, Issue-6, page 196-203.

8. Ankita Mishra, Kapil International journal of scientific \& engineering research Volume 5 Issue VI, June 2017 IC Value: 45.98 ISSN: 23219653.

9. IS 13920: 1993 "Ductile detailing of reinforced concrete structures subjected to seismic forces- code of practice" Bureau of Indian standard, New Delhi. IITK-BMTPC: Earthquake Tips.

10. Bureau of India Standard, IS-1893, Part-1 (2002), "Criteria for earthquake resistant design of structures." Part 1

11. Bureau of Indian Standard, IS-456(2000), "Plain and Reinforced Concrete Code of Practice".

12. Duggal S.K. (2010), "Earthquake Resistant Design Structures". Oxford University press YMCA library building, Jai Singh Road, New Delhi.

\section{AUTHORS PROFILE}

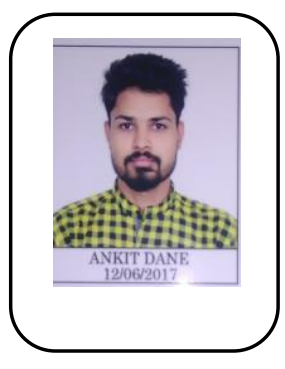

First author Name is Ankit Dane 25 years old localized of Indore and completed his engineering from astral institute of engineering and research, Indore and in present he pursuing masters in specialization of computer aided structural design and drafting branch from Ujjain engineering college, Ujjain, M.P., INDIA. Mail ID. - ankitdane1234@gmail.com

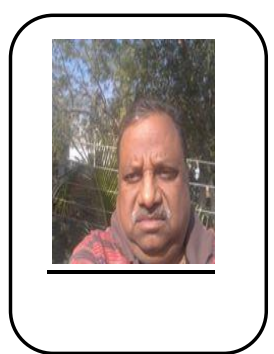

Second Author The second author of the presented paper Dr. Umesh Pendharkar They are the professor of, Department of Civil Engineering, Ujjain engineering college, Ujjain, INDIA. They publish many research papers related to civil engineering. Dr. Umesh Pendharkar is the guide of Ankit dane in thesis of $\mathrm{m}$. tech. they have 14 research items, 848 reads and 141 citations in present with highest qualification of PH.D.

Mail ID- upendharkar@gmail.com 